\title{
Homeobox Protein Hox-C10
}

National Cancer Institute

\section{Source}

National Cancer Institute. Homeobox Protein Hox-C10. NCI Thesaurus. Code C116304.

Homeobox protein Hox-C10 (342 aa, $38 \mathrm{kDa}$ ) is encoded by the human HOXC10 gene.

This protein is involved in embryonic pattern specification. 